\title{
Universiteit
}

Leiden

The Netherlands

\section{Rule of Law Promotion, Land Tenure and Poverty Alleviation: Questioning the Assumptions of Hernando de Soto \\ Otto, J.M.}

\section{Citation}

Otto, J. M. (2009). Rule of Law Promotion, Land Tenure and Poverty Alleviation: Questioning the Assumptions of Hernando de Soto. Hague Journal On The Rule Of Law, 1(1), 173-194. Retrieved from https://hdl.handle.net/1887/14121

Version: $\quad$ Not Applicable (or Unknown)

License: $\quad$ Leiden University Non-exclusive license

Downloaded from: https://hdl.handle.net/1887/14121

Note: To cite this publication please use the final published version (if applicable). 


\title{
Rule of Law Promotion, Land Tenure and Poverty Alleviation: Questioning the Assumptions of Hernando de Soto
}

\author{
Jan Michiel Otto*
}

'W hat we try to do at the IL $D$ [the Institute for $L$ iberty and $D$ emocracy] is build up a legal system of property that is based on the realities already on the ground.'

Hernando DE SOTO (interview by Jeremy $\mathrm{Clift}^{1}$ )

'A nd so formal property is this ex traordinary thing, much bigger than simple ownership.'

Hernando DE SOTO ${ }^{2}$

'H ow much security of tenure is enough? There was a time when (W orld) B ank task managers would have been comfortable with nothing less than full private ownership, with all the freedom of action that confers. $\mathrm{H}$ owever, experience and research have in recent years provided evidence that use rights, customary rights and leasehold rights can provide farmers with seaurity of tenure suffident to their needs.'

John BRUCE ${ }^{3}$

\section{INTRODUCTION}

It is fairly easy to make recommendations for 'rule of law promotion' or 'rule of law reform' in developing countries until one starts to discuss concrete problems and situations. In concrete situations we often find that the laws of a particular

* Professor of Law and Governance in Developing Countries at the Faculty of Law, Leiden University, and Director of the Van Vollenhoven Institute for Law, Governance and Development. He would like to thank Janine Ubink, Andre Hoekema, John Bruce, and Stephen Golub for their substantive comments on earlier drafts, and Stephen Golub, Randy Peerenboom, Julio Faundez and Marilyn Hedges for their editorial suggestions. In particular, he thanks John Bruce for sharing his insights in the main reasons of De Soto's success. Professor Otto can be contacted via: j.m.otto@ law.leidenuniv.nl.

${ }^{1} \mathrm{~J}$. Clift, 'Hearing the Dogs Bark'. Jeremy Clift interviews development guru Hernando de Soto, $F$ inance and D evelopment, December 2003, pp. 8-11.

${ }^{2}$ H. de Soto, The M ystery of Capital, 2000, p. 235.

${ }^{3}$ J. Bruce, 'Reform of Land Law in the Context of World Bank Lending', in J. Bruce, et al., L and L aw R eform, 2006.

\section{CAmbridge J JURALS}


developing country are so unstable, unclear, layered and fragmented that basic elements of the rule of law are not met or hardly met, and causal relations between law, governance and development cannot readily be assumed. In such concrete situations we also often find that practical realization of rule of law standards is hampered by contextual factors of a political, administrative, economic and social nature, irrespective of the legal texts.

All this is definitely the case with matters of land tenure in developing countries. Therefore the very fact that Hernando de Soto's 2000 book The M ystery of Capital caught the attention of many national governments with a grand design for aid policies which project legalization of informal land assets of poor people as a major contribution to reducing world poverty, is phenomenal by itself. Previously he had attracted considerable international notice with his 1989 book The 0 ther Path, ${ }^{4}$ arguing that bureaucracies and state regulations in developing countries tend to hinder rather than help small businesses, forcing them into unregistered, informal, 'extra-legal' existence. De Soto's 2000 book was also warmly received in the higher echelons of international politics and development policymakers, perhaps most notably in the United States during the presidency of George W. Bush, as a work of great innovation.

In 2005 his ideas on law and property, and the advocacy efforts of De Soto himself, provided the initial impetus for the UNDP to establish the Commission on Legal Empowerment of the Poor, co-chaired by former Secretary of State Madeleine Albright and De Soto. During the three years of its preparatory activity and subsequent meetings, the Commission expanded its scope beyond De Soto's concern with legalization of informal businesses and of the informal land assets of the poor. Thus, both chairpersons in an article in Time M agaz ine (16 July 2007) called for joint global action 'to give the poor a platform for demanding legal rights, and to hold political leaders accountable for responding.' The focus shifted to a somewhat broader notion of legal empowerment than that previously advocated by De Soto - though not as broad as implied by the sweeping declaration in the Time article. Thus, in its 2008 final report, 'Making the Law Work for Everyone', the Commission ${ }^{5}$ accordingly arrived at 'four pillars of legal empowerment'. In addition to incorporating De Soto's emphasis on 1) property (essentially land) rights and 2) what it called 'business rights' (focusing mainly on issues pertaining to informality, registration and the like), the Commission added 3) labor rights and 4) access to justice and the rule of law (with legal identity as a cornerstone but an assortment of other considerations taken into account).

${ }^{4}$ H. de Soto, The 0 ther Path: T he Invisible R evolution in the T hird W orld, 1989.

${ }^{5}$ Commission for Legal Empowerment of the Poor, $M$ ak ing the L aw W ork for $E$ veryone. Volumes I and II, 2008. 
Despite the Commission's somewhat broadened perspective, De Soto's thesis still resounds in many sections of the report as well as in the comments on the report. For example, according to the reaction of Norwegian Minister for Development Cooperation Erik Solheim,

'It is unacceptable that poor people are not protected by the rule of law (...). These are rights that those of us living in rich parts of the world take for granted. Without property rights, for instance, it is difficult to get a loan. Everything you own can simply be taken away from you, just like that. It would make a big difference to food production if farmers in poor countries owned the land they work. There would be a far greater willingness to invest, and more opportunities to do so. This is why rights of this kind are so crucial for economic development in poor countries. $^{.6}$

As reflected in this quote, part of the attractiveness of De Soto's design is the suggestion that it can all really be done. A key argument of the 2000 book is that this is in fact how the West became wealthy: it used property law to incorporate all people into the formal sector. In other words, the direction is clear; what are we waiting for?

And even though the approach taken by the Commission is broader and more nuanced, to the average policy-maker and to many readers of his 2000 book, De Soto's design still seems to be the most compelling, coherent and promising story which links rule of law promotion to poverty eradication. At the same time, it has raised many questions and has been heavily criticized from different sides.

In this article I will first present the main thrust of De Soto's design, and then summarize praise and criticisms of his work. Next, I will address the question of to what extent De Soto's design is innovative. To this end I present a brief overview of past experience. I will then introduce some preliminary results of an international Leiden-based research project that has addressed the general causal relations between legalization, tenure security and poverty alleviation which constitute the basis of De Soto's argument. Most case studies of this project found that for De Soto's plans to be effective, a range of conditions had to be fulfilled. As long as these conditions are not fulfilled - which happens to be the unfortunate reality throughout the developing world - his plans will not work. Unfortunately, his proposals then are based on a whole set of unrealistic assumptions. Finally, in order to place De Soto's work in the context of today's development policies, with their emphasis on good governance and rule of law promotion, I will present a conceptual scheme which unpacks the key concepts of develop-

\footnotetext{
${ }^{6}$ http://www.norway-un.org/News/News+Archive/061608_MakingtheLawWorkfor Everyone.
} 
ment, governance and the rule of law. In the concluding part I speculate on what we can learn from the success of De Soto's compelling theories, and from various criticisms of and responses to them How can these lessons be beneficial for a realistic rule of law promotion?

\section{De Soto's Proposal and Strategies: From Land Law to Tenure Security to Poverty Alleviation}

Let me start with a few introductory remarks about Hernando de Soto himself to shed some light on the circumstances in which he developed his ideas. De Soto grew up as the son of a Peruvian diplomat, a jurist who served with the ILO in Europe. After years of study and work in Switzerland, De Soto returned to Peru at the age of 38. There, he, a Peruvian who had grown up, lived and worked in the western world for so long, becoming accustomed to the type of efficiency common in industrialized countries, started to look at Peruvian society from the comparative perspective of a foreigner. In Lima, Peru, he found out to his amazement that small entrepreneurs were not helped, but instead enormously hindered by the host of existing regulations and the way bureaucrats applied them. Establishing a simple, small enterprise, he calculated, took 289 days and cost 31 times the average monthly minimum wage. No wonder, he concluded, that most enterprises prefer to stay outside the formal sector and remain in the informal sector.

He established the Institute for Liberty and Democracy in Lima, and went into research, consultancy and politics. When in 2000 in his book The M ystery of C apital De Soto makes an appeal to the international community and to Third World governments for legalization, he focuses not on small businesses in urban areas but on the informal land assets of the poor. Their 'dead capital', he argues, could be turned into economic progress. The book recommends that the poor should quickly move their land assets from an unproductive extra-legal sphere into the legal sphere where these assets could turn into 'capital'.

Criticizing the standard registration and legalization projects which have been carried out so far, De Soto proposes a twofold strategy for legalization. Its first part consists of the 'discovery' and analysis of the informal 'social contracts' that currently regulate most man-land relations in poor regions. The second part is a legal and political strategy for designing ways to connect, harmonize and integrate those rules with the formal legal system. ${ }^{7}$

${ }^{7}$ The process of discovery (A) consists of five stages: A1. Identify, locate and classify extralegal assets. A2. Quantify the actual and potential value of extralegal assets. A3. Analyze the interaction of the extralegal sector with the rest of society. A4. Identify the extralegal norms that govern extralegal property. A5 Determine the costs of extra-legality to the country. Constructing the 'bridge' (B) calls for a political and legal strategy in six stages: B1. Ensure that the highest political level 
In a chapter entitled 'The mystery of legal failure', De Soto addresses the worldwide failures of lawyers to build legal systems that are accessible to all classes in society. In developing and transitional countries, he argues, only a small capitalist sector has been able to turn its resources into capital by recording its legal rights, but the rest of society holds its possessions in legally defective forms. 'They have houses but not titles; crops but not deeds; business but not statutes of incorporation' (De Soto, The M ystery of C apital, p. 7). Therefore 'their assets cannot readily be turned into capital, cannot be traded outside narrow local circles where people know and trust each other, cannot be used as collateral for a loan, and cannot be used as a share against an investment' (idem, p. 6).

Closer reading of De Soto's critique reveals that he observes two different kinds of 'legal failure'. The first is a failure to enact adequate reform law, i.e., no 'bridges' are built so that the poor must remain outside the legal sphere, which De Soto calls 'the bell jar'. The second is a failure to make the law work. In the latter case reform law is enacted, efforts are made to construct 'bridges' and to lift the bell jar, but to no avail.

Concerning the first type of failure, De Soto finds that the 'existing law does not address the needs and aspirations of the poor' (idem, p. 154). He explains that the law is not made by the right people but 'by lawyers in high-rise offices in Delhi, Jakarta or Moscow [who] are hired to draft laws' (idem, p. 178). He observes that law-makers lack interest in existing local practices: 'When trying to ensure property rights of poor people, governments behave as if the place has a property vacuum' (idem, p. 170). 'The law-makers fail to find out why and how the local conventions work and how strong they actually are. They fail to assemble extralegal contracts to build a property ... system' (idem, p. 162). Obviously, the consequence of all this is that 'existing legal norms are not rooted in social contracts to which people were already committed' (idem, p. 173). De Soto concludes that 'the official legal sector does not interact with extra-legal arrangements outside the bell jar' ... so that a situation of 'legal apartheid' exists (idem, pp. 158-159). As a result, De Soto maintains: 'formal law is increasingly losing its legitimacy as people create property beyond its reach.'

De Soto's discussion of the second type of legal failure raises some doubts about the accusation of the first type. De Soto demonstrates that in countries like Peru reform laws were actually promulgated. They did declare the poor as the

assumes responsibility for capitalisation of the poor. B2. Put into operation agencies that will permit rapid change. B3. Remove administrative and legal bottlenecks. B4. Build consensus between legal and extra-legal sectors. B5. Draft statutes and procedures that lower costs of holding assets legally below those of holding them extra-legally. B6. Create mechanisms that will reduce risks associated with private investment, including credibility of titles and non-payment for public services (De Soto 2000). 
legitimate owners of the land. But then, 'none of them worked' (idem, p. 166). There have been many well-funded land registration projects, but most of them were 'prematurely aborted because of poor results' (idem, p. 169). One of the legal causes, according to De Soto, was that 'many legal procedures to create or modify property do not accept extra-legal proofs of ownership or transfer that lack any visible chain of title' (idem, p. 166). In many countries the process of recording titles takes so long and is so hazardous that people create 'extra-legal rules to protect their assets' (idem, p. 166). In the meantime, 'economic elites swung back into action, dreaming up new tricks to circumvent the law's intent (...) and establishing new titles to unrecorded land' (idem, p. 166). When the government's response, as for example in Peru, came in the form of laws aimed at the protection of indigenous peoples - by reserved areas or agricultural cooperatives - this had the negative side effect of sealing off such communities from the basic tools of creating capital (idem, p. 167). Obviously, De Soto acknowledges that there is more to legal failure than negligent law-makers. The bureaucracy that must carry out registration programmes may be largely ineffective and corrupt. The power of economic elites can be too strong to be restricted by legislation. Socialist politics may succeed in protecting the poor by ensuring some minimal access to benefits, but not in mobilizing their economic potential. Clearly, there are a host of nonlegal factors at play. ${ }^{8}$

\section{Praise and Criticisms of De Soto's Work}

De Soto's work has received much praise from Western politicians and economists. As early as 1989 George Bush Sr. noted in a presidential speech:

'The Peruvian economist, Hernando de Soto, has helped us understand a worldwide economic phenomenon. By walking the streets of Lima, not analyzing official statistics, he found that the poor of Latin America - who have never read Jefferson or Adam Smith - ran their affairs democratically, outside the formal economy, organizing their private, parallel economy, in a free and unregulated manner. De Soto's great contribution has been to point out what, in retrospect, may seem obvious: people everywhere want the same things. When left alone by government, people everywhere organize their lives in remarkably similar ways. De Soto's prescription offers a clear and promising alternative to economic stagnation in Latin America and other parts of the world. Governments must bring

\footnotetext{
${ }^{8}$ The 'typically legal' problem of proof of property, is easier to solve. Legal NGOs have already found ways to help local communities establish their property rights where no visible chain of titles exists. Their methods include 'community mapping' and interviews, requiring much time, money and, most of all, a deep insight into local culture, politics and economics, in which local land rights are embedded.
} 
the informal workers into the regular economy and then get out of the way and let individual enterprise flourish' (Bush Sr. 1989).

President Bill Clinton also praised De Soto's work in public. T ime M agazine (May, 1999) chose De Soto as one of the five leading Latin American innovators of the century, and other magazines ranked him among a select group of the world's top public intellectuals, innovators, etc. In 2006, TheE conomist magazine honored him with the Award for Social and Economic Innovation, for his promotion of property rights and economic development.

On the other hand, many academics, practitioners and activists have criticized De Soto. In fact, it is difficult to find many serious academics in the areas of land tenure, development studies or socio-legal studies who are very impressed with De Soto's work. Well-known land tenure experts, such as John Bruce, Julian Quan, Patrick McAuslan or Geoff Payne, all find De Soto's theories full of sweeping generalizations that oversimplify or are even misleading. In particular they note that De Soto has ignored most of the empirical literature about the many efforts previously made in pursuit of the kinds of goals he advocates. Several of De Soto's central claims have already been refuted by a considerable number of field studies, which concluded that:

- De Soto's type of legal engineering does not work in environments where legal and administrative institutions are not very effective, and where legal uncertainty and corruption prevail, i.e., in most of the target countries;

- many poor people prefer informality for quite understandable social, economic and political reasons;

- legalization of small, informal assets of poor people often does not lead to increased access and use of formal credit.

Legal anthropologists such as Von Benda Beckmann ${ }^{9}$ are similarly indignant about De Soto's seeming ignorance of how patterns of interaction between local communities and public officials, as well as within communities, make land registration projects fail. Financial analyst Robert Samuelson criticized De Soto in F oreign A ffairs ${ }^{10}$ for his 'silver bullet' approach. Alan Greenspan ${ }^{11}$ (2007) in his memoirs similarly recalls De Soto's visit as the incredible story of someone who goes for one single solution overlooking several major problems.

\footnotetext{
${ }^{9}$ F. von Benda-Beckmann, 'Mysteries of capital or mystification of legal property', $41 \mathrm{~F}$ ocaal. E uropean Journal of A nthropology (2003), pp. 187-191.

${ }^{10}$ R. Samuelson, 'The Spirit of Capitalism', (80) 1 F oreign A ffairs (January/February 2001).

${ }^{11}$ A. Greenspan, The age of turbulence A dventures in a new world, 2007.
} 
Given the breadth and depth of the criticisms, one could wonder why De Soto's star has still shone so brightly. Slightly rephrasing an excellent analysis by John Bruce, ${ }^{12}$ I propose four main reasons. First, De Soto is a brilliant story-teller. The style of his book is very confident and convincing. Secondly, he tells what most policy-makers and people want to hear, namely that there is a solution to all their problems, and that this solution combines all the goals of development and governance without problems or contradictions; the only condition is that we all stop being stupid. Thirdly, his story fits well in the dominant political and economic trends of neo-liberalism. Finally, most practitioners in land law and development, policy-makers, consultants and even academics do not speak out against him because they are faced with a difficult dilemma. On the one hand, here is a relative newcomer to an area they have worked in for decades, who makes claims that they find wildly exaggerated. On the other hand, finally here is someone who, more than anyone before, has promoted the importance of their field, of the rule of law, especially land law for economic development. So, even if he is incorrect, it would not be wise to dismiss his message.

\section{De Soto in Historical Perspective: Innovation or a Beaten Path?}

During the $19^{\text {th }}$ century the land laws in most colonies in Asia and Africa followed a general pattern of legal dualism - in other words, European-type land law for the Europeans, indigenous customary law for the native population. In the last decades of British and French colonial rule, the policy of legal dualism shifted towards one of national integration of laws and legal institutions, following European legal models $\left(\right.$ Allott $\left.^{13}\right)$. The idea took hold that economies in Asia and Africa would develop more rapidly if land held under customary tenure were to be incorporated in an integrated national system of land law and administration. In this respect De Soto's argument is not new. In this late colonial era the European ideology of social and economic liberalization became one of the principal exports to the colonized territories. While foreign plantation companies and local entrepreneurs were changing the orientation of agriculture, from subsistence economy to cash crop production for domestic and foreign markets, many colonial jurists cherished the 'centralist' idea that western-type law had qualities superior to the indigenous type, and anticipated a swift conversion from customary communal tenure to individual freehold rights. As Allott (idem, 191-2) describes, the East-African Royal Commission, 1953-5 favored a 'policy concerning the ten-

${ }^{12}$ J. Bruce, 'Simple Solutions to Complex Problems: Land Formalization', in J.M Otto, et al. (eds.), $L$ aw and $L$ and Tenure Security in D eveloping $C$ ountries: the $L$ auds and $L$ imits of $L$ egalization, 2009 (forthcoming).

${ }^{13}$ A. Allott, The L imits of L aw, 1980, p. 183. 
ure and disposition of land [which] should aim at the individualization of land ownership, and at a degree of mobility which, without ignoring existing property rights, will enable access to land for its economic use.' In Kenya the 1953 official 'Plan to Intensify the Development of African Agriculture in Kenya' envisaged a system of tenure which would provide the farmer with 'such security of tenure through an indefeasible title as will encourage him to invest his labor and profits into the development of his farm (...).' These policies and laws, though, were to meet strong resistance since they meant the elimination of community rights and powers over land, and the squeezing out of many farmers.

French colonial jurists had also departed from the idea that introduction of a French-type civil law would be in the best interest of the economic development of African farmers. Others, like the Dutch Professor Van Vollenhoven and his A datrechtsschool, held a more 'localist' view, and pleaded for continued recognition of indigenous law and communal tenure. ${ }^{14}$ To this end, Van Vollenhoven and his colleagues developed the hybrid concept of 'adat law' as a conceptual bridge between adat (custom) and law.

After independence, in the 1950s and 1960s unification, modernization, liberalization and transformation even became key words of the new law-making elites (Allott, idem). The influence of European jurists decreased markedly, and their advice was mostly limited to technical-legal matters. ${ }^{15}$ The impact of the new legislative policies has been disappointing. The great ambitions and hopes for rapid unification and modernization were rarely realized; countervailing powers had been grossly underestimated.

In the 1970s and 1980s Western concerns with the laws of developing countries were redefined in terms of international human rights law, and thus gradually

${ }^{14}$ Concerning the Netherlands Indies, vehement debates about the future of the colony's legal system took place during the first decades of the $20^{\text {th }}$ century, with the focus on land tenure issues. The debate, often cited as the Leiden-Utrecht controversy (Burns, The L eiden $L$ egacy. C oncepts of $L$ aw in Indonesia, 1999) featured a 'Leiden' school led by Professor van Vollenhoven claiming that for native Indonesians the indigenous adat laws should remain the foundation of the legal system. This school argued that most Indonesian land belonged to Indonesian native communities, and that the colonial state should legally, by recognition of their adat law, preserve this land for them. 'Utrecht' however, led by Professor Nolst Trenité, and associated with the economic interests of Dutch colonial enterprise, claimed that the introduction of a unified civil legislation would stimulate land markets in the best interests of both the native as well as the European population groups. After protracted and intense polemics, Van Vollenhoven's views prevailed in parliament and state policies and law. Dutch colonial law continued to recognize adat law as the private law of the indigenous population. This adat law policy was supported by an immense body of knowledge, collected by dozens of field researchers of the 'A datrechtsschool', which could not be effectively countered by Utrecht.

${ }^{15}$ Not hindered by a colonial past, a US-based 'law-and-development movement' took off in the 1960s and 1970s. See B.Z. Tamanaha, 'The lessons of law and development studies', 89 A merican Journal of International L aw (1995), pp. 470-486. 
extended to more delicate areas such as non-discrimination law, criminal procedure, labor law and legal aid. Still, land law was considered by many Third World governments as an area too complex, too sensitive and too political to involve foreign experts. At the time, only a few donor institutions and a limited number of land law and development specialists were active in the field. ${ }^{16}$ The declared purpose of their involvement was - and still is - to strengthen land law systems making them more effective, efficient, consistent and responsive - and help implementing them - thus increasing their effective scope and reach in urban and rural areas. Meanwhile, most donors had not paid much attention to the possibility of strong causal relations between law reform and poverty reduction, except, in a general sense, in the domain of human rights. Doubts about such causal relation have put 'law reform programs' in a rather inferior position on the priority lists of donors. Perhaps as a consequence, in the 1970s and 1980s donor institutions did not create a sizable community of 'law-and-development' experts as found in other sectors of foreign aid such as food and agriculture, health, education, housing and the environment.

Since the rise to prominence in the early 1990s of 'good governance', with 'the rule of law' in its slipstream, international legal transfers and cooperation projects in the area of land law have increased significantly. Currently, they include projects by the World Bank and the regional development banks, by sustainable land management experts of FAO and IIED, by urban housing experts of UN-Habitat, by surveyors united in the International Federation of Surveyors, by international legal drafters of land reform from the Rural Development Institute (RDI), by legal anthropologists and other academic researchers, by rights-based NGOs such as the Centre On Housing Rights and Evictions (COHRE), and by the land tenure experts of De Soto's Institute for Liberty and Democracy.

The so-called 'rights-based approach to development', which has now become quite popular with donor agencies, sets the realization of human rights - the substantive dimension of the rule of law (see below) - as the prime objective of development policies. While it has often been said that courts cannot enforce social and economic human rights, the innovative legal developments that been taking place in South Africa since 1996, are closely watched in other African, Asian and Latin American countries. ${ }^{17}$ In the discourse surrounding De Soto's design

${ }^{16}$ The donors included the World Bank (for efficient land administration), the FAO (for rural development and agricultural production) and UN Habitat (for low-income housing). The land law experts included Roy Prosterman (for land reform), Patrick McAuslan (for urban development), John Bruce (for land tenure in Africa), and Liz Alden Wily (for customary tenure). For a critical assessment of the role of western land law experts in 'bringing the law back in' in land reform in Tanzania, see A. Manji, 'Cause and consequence in law and development', 43 Journal of M odern A frican Studies 1 (2005), pp. 119-138.

${ }^{17}$ Section 25(5) and section 26 of its 1996 Constitution provide that the state must take reasonable legislative and other measures, within its available resources, to foster conditions [that] enable 
'the poor' also play a key role, but neither as victims of eviction and repression nor as the subjects of human rights. In De Soto's plans the poor figure as small entrepreneurs who so far have been denied access to the benefits of the state legal system. In essence, this perspective is not very different from the late colonial policies of 'integration' and the post-colonial legislative policies informed by the principles of unification, modernization and liberalization mentioned above. Those policies had often failed. Why would De Soto's plans enjoy a better fate?

\section{The Leiden Project: Some Preliminary Field Findings}

Intrigued by the mix of praise and critique of De Soto, a group of Dutch researchers decided in 2003 to undertake a comparative socio-legal research project on the background, potential and effects of De Soto-style initiatives on the ground. An international group was formed to carry out country and case studies in eight countries in Asia, Africa and Latin America. ${ }^{18}$ The group explored how initiatives for land tenure legalization evolved in the context of national land law regimes, to what extent these initiatives contributed to land tenure security, whether they reached the poor, and to what extent they brought economic advantages such as better access to credit. Given the diversity of cases and contexts, we defined legalization broadly as 'a process whereby possession (including use) and management of a tract of land are incorporated into a national legal system - either directly, or indirectly through recognition of community-based rights - whereby the rights and obligations of individuals or collective entities are defined.' This phenomenon of legal incorporation is the common denominator of all cases in the project and also the cornerstone of De Soto's approach. De Soto, though, is specific in that he proposes a design of rapid and massive direct incorporation through national programs for systematic titling and registration of plots as individual, transferable property. Our group looked at such approaches, but also at cases of gradual, piecemeal or indirect incorporation, which not always included titling and registration, nor did they necessarily deal with individual plots. The case studies are currently in their final stages. Some preliminary results can be gathered from workshops and conferences organized by the group. The following summarizes the results of three of the case studies.

citizens to gain access to land and to housing on an equitable basis. The Constitutional Court of South Africa, while ruling on the right to housing in the 2000 Grootboom case - and similarly on access to land in the 2002 Treatment Action Campaign case - decided that 'the state must foster conditions to enable citizens to gain access to land on an equitable basis. Those in need have a corresponding right to demand that this be done.' (G rootboom case, para 93, as cited in Lahiff and Rugege 2006; Liebenberg 2006). The court also ruled that the right to housing includes land, dwelling and services, and that special attention should be given to the needs of the poor.

${ }^{18}$ China, Indonesia, Ethiopia, Ghana, Tanzania, Senegal, Mexico, Bolivia, later followed by Egypt and Namibia. 
1. Kojo Amanor ${ }^{19}$ (2009) has contributed a case-study on land legalization in the rural Brong Ahafo Region, Ghana. Legalization of land in this case is in the interest of tree planters. Amanor argues, however, - and what follows below is mainly a direct quote from his forthcoming book chapter - that the processes of legalizing or formalizing the land holdings of peasant farmers do not necessarily lead to increasing security of tenure among the poor, but frequently create more insecurity. The process of securing rights through legalization usually creates new avenues for investment and the accumulation of land and wealth, which frequently undermines the land rights of the poor.

From early times the area has been inhabited by local food crop farmers, who cultivate yam. For these farmers, land is a mobile resource base, as they are bush fallow cultivators who do not remain in one place but move around. According to customary land practices, they have land allocated by their chiefs but not as a demarcated area. They can clear as much land as they are able based on their strength and ability to hire labor, until they meet other farmers clearing up to their farms. The tree planters usually constitute the richer segments of the population with surplus capital to invest in hiring labor. They have become worried that elders in the family will prevent their children from inheriting their plantations. These worries translate into an interest in titling their plantations to further secure their wealth. Tree planters therefore tend to be highly amenable to programs concerned with land titling and extending secure property rights to those who have acquired their land in the customary sector. Various donor-supported programs are assisting new export sector tree crops, and these programs are promoted as poverty reduction programs. They frequently develop components concerned with security of customary land tenure and securing land rights for the poor. Paradoxically, these tree planters will constitute a major clientele for these programs in years to come, since tree plantations are fungible assets, which are easily mapped and demarcated, unlike the mobile resource base of bush fallow cultivators. This expansion of tree planters with registered holdings will ultimately serve to undermine and erode the base of the food crop farmers and of their system of land use.

In reality, Amanor writes,

'a large gulf exists between the dynamic land use systems based on use rights and recycling of land, and the visions of a customary system based on clearly defined and fungible property rights. The transition from the one system to the other is unlikely to occur without the considerable appropriation of land from the poorer sections of farmers. It is perhaps this appropriation of common property and fam-

${ }^{19}$ K. Amanor, 'Tree Plantations, Agricultural Commodification and Land Tenure in Ghana', in J. Ubink, et al. (eds.), Tenure security and $L$ egalization of $L$ and in D eveloping W orld: C ountry studies and $C$ ase studies, 2009 (forthcoming). 
ily user rights that will redefine land assets and create the basis for individualized land tenure security based on legalization and the rule of law, so loved by De Soto and advocates of the new institutional economics.'

2. Marco Lankhorst and Muriel Veldman ${ }^{20}$ (2009) have contributed a case-study on urban dwellers living in informal settlements in a small town in Namibia, Otjiwarongo. They examined to what extent settlers would make use of options for legalization if new draft legislation, the so-called Flexible Land Tenure Bill ${ }^{21}$ were introduced. Contrary to Amanor's Ghana case, the impact of traditional leaders and customary law was rather limited in this context. These settlements had been constructed on land owned by the local government. Rural people had been given permission to build in zones assigned for that purpose. Formally, they have rented the land from the local government. While in other areas in Namibia it is possible to obtain land in freehold ownership, this option had not yet been offered to the settlers in Otjiwarongo. The new Bill has two main objectives, i.e., better tenure security and more economic opportunities. It is sophisticated in that it acknowledges the main problems of previous land registration programs in Namibia and tries to provide solutions which would well classify as a 'bridge' between extralegal and legal as defined in De Soto's policy theory (see section 2). In Namibia those problems, according to Lankhorst and Veldman have been twofold, namely the institutional weaknesses of land registration authorities as well as the financial barriers which impede the participation of the urban poor in such programs, and in the commercial land market in general. So, the Bill would offer simplified registration procedures and reduced costs. It would introduce two new simple forms of tenure. First, the 'starter title' for plots as parts of group managed blocks, and secondly, the 'land hold' title, which approaches freehold more closely. In both cases the block can be registered at very low costs as a single entity in freehold ownership, listing the owners as members of a starter or land hold title association. The starter title is easy to obtain and can later be upgraded to the level of 'land hold' title.

Lankhorst and Veldman investigated whether such flexible titling would indeed bring more tenure security and economic opportunities to the inhabitants. They therefore asked them to what extent they felt insecure about their land hold-

${ }^{20}$ M. Lankhorst and M. Veldman, 'Titling or Accommodating Informal Urban Institutions? A Namibian case study on the prospects of improving tenure security under the Flexible Land Tenure Bill', in J. Ubink et al. (eds.), Tenure security and $L$ egalization of $L$ and in $D$ eveloping W orld: C ountry studies and $C$ ase studies, 2009 (forthcoming).

21 The idea for this Bill had originated from some Danish donor institution, personal communication, Robin Palmer (Oxfam), Leiden, 26-29 September 2007. 
ings and why. A considerable number felt so insecure that they did not undertake any improvements to their homes. The main source of this insecurity happened to be the administrative practice of local government to relocate the settlers from one zone to another. The new Bill would not be able to solve this problem due to legal-technical reasons; individual title certificates and permanent building in a certain zone would have to wait until new spatial plans had been enacted for that zone. So, this tenure insecurity would not be reduced by a system of low-cost titling and registration. Neither did Lankhorst and Veldman find that the bill would offer real material benefits in terms of opening access to credit to significant portions of the population. Banks would not find the poor settlers sufficiently creditworthy. For the urban poor micro-financing programs and savings groups seemed to offer better prospects. And lastly, the existing state of informal land tenure appeared to give the settlers more economic freedom than a legal regime as envisaged by the Bill. In sum, Lankhorst and Veldman found that urban settlers in Otjiwarongo were not primarily worried about the weakness of their private land rights. The fact that their houses did not meet administrative law requirements was at least as great a concern. So, titling, even gradual or flexible titling, it seemed, would not offer them more tenure security or any other material advantages.

3. Gustaaf Reerink has contributed a case on urban dwellers in seven kampungs in Bandung, Indonesia. His findings teach us that land registration does not inherently lead to legal security for landholders. According to Reerink ${ }^{22}$ it is often assumed that land registration automatically generates legal security for participants and consequently enhances their de facto tenure security. In the cases investigated registration has not led to legal security, as kampung dwellers had failed to fulfill other legal requirements. Yet, there are clear indications that it did increase participants' de facto tenure security. Tenure security, Reerink found, ultimately depends on the way state authorities and third parties actually value (the lack of) land certificates and other documents required to reside on land, for instance in the case of land acquisition, which is often more influenced by political considerations than by legal norms. Besides, registration of land may strengthen the landholders' own perceptions of tenure security. It falls outside the scope of this paper to discuss this in detail, but further data from the current research show that in PostNew Order Bandung the actual tenure security (measured by interference from third parties) of low-income kampung dwellers holding land certificates (but often not fulfilling other legal requirements) as well as their perception of tenure secu-

${ }^{22}$ G. Reerink, 'Land Registration Programs for Indonesia's Low-income Slum Dwellers: Need, reach and effect in the Kampungs of Bandung', in J. Ubink, et al. (eds.), Tenure security and L egalization of $L$ and in D eveloping W orld: C ountry studies and C ase studies, 2009 (forthcoming). 
rity is stronger than among those who do not have such documents. ${ }^{23}$ This, for instance, also means that the former invest more in their land and housing than the latter.

Djaka Soehendera ${ }^{24}$ (2006) found in a related case-study in a poor neighborhood in Jakarta, Kampung Rawa, that a large-scale registration program in practice did not reach the poorest landholders. He found that after an intensive land registration program only 43 percent of the population could obtain a land certificate and that this group generally included the more affluent.

These three cases reinforce the general conclusions that can be drawn from most published studies of land registration in developing countries, namely (a) that land registration is often insufficient to provide full legal security, (b) that land registration programs are often utilized by upper and middle class land holders while the poor, the marginalized, the women, the youth, the migrants, the pastoralists, and slash-and-burn farmers are often not included, (c) that land registration often fails to realize its promise to the poor of increased access to credit as their key to economic growth.

\section{De Soto’s Mistaken Assumptions}

It is too early to present final conclusions from our field studies. But it is fair to say that, over the course of the bi-annual meetings which the international research team has conducted since 2005, doubts about the causal relations between legalization of land tenure, tenure security and poverty alleviation have steadily increased. Although De Soto's theories may prove to be right in certain areas under certain conditions, most of the case studies concluded that in reality such conditions remained unfulfilled. Thus, De Soto's theories seem to be based on mistaken assumptions about the context of legalization projects which, according to our preliminary field data, often did not hold. Some such assumptions are related to a given country's legal system itself, while others have to do with the law's political, administrative, economic or social contexts. These mistaken assumptions can be summarized as follows.

${ }^{23}$ A distinction should however be made between on the one hand formal and customary landholders and on the other hand informal landholders. Whereas the tenure security of formal and customary landholders is comparably high, informal landholders enjoy relatively little tenure security. This indicates that registration programs could particularly benefit the latter.

${ }^{24}$ D. Soehendera, Sertipik at Tamah dan 0 rang M isk in, K asus Kampung R awa, Jak arta, 2006. 
(1) A bout law:

1.1 L egal systems can be qualitatively strengthened by project interventions so that their legal institutions will effectively enforce property law in accordancewith therule of law. However, an appropriate rule-of-law environment is often still beyond reach. For example, many courts in developing countries are not effective in providing access to justice and protecting farmers against land predators;

1.2 Property laws contain legal designs supportive of the poor. However, such legal designs are often absent, due to the prevailing neo-liberal ideology of market-led growth. 1.3 B etter private property law will create tenure security. However, the causes of legal insecurity often include the dwellers' violation of administrative regulations, such as building regulations, land use regulations, spatial planning regulations, tax and retribution regulations.

(2) A bout politics:

2.1 The political elites of states are willing to relinquish their grip on the most valuable re sources they can dispose of, i.e, land and natural resources. However, political elites and state administrators in developing countries are unlikely to relinquish the wide powers they have to manage and dispose of land.

2.2 L ocal dwellers can make decisions about their land without being restricted by local power holders, their patrons and chiefs. In reality, local power holders, including chiefs, supported by higher political elites, often keep a tight grip on land in developing countries. Quite often they use this for the benefit of themselves and their families, and countervailing power is lacking.

(3) A bout administration:

3.1 The attitude and motivation of land agency officials and administrative leadership will generally be pro-poor and not influenced by ethnic preferences or bribery. This assumption seems incorrect in the light of research evidence as well as practitioners' experience concerning public administration in developing countries, where ethnic considerations and bribery play major roles and pro-poor attitudes are the exception to the rule. ${ }^{25}$

3.2 G overnment officials will refrain from forcibly evicing and relocating the poor and will not be swayed by related economic devel opment arguments or undue influences, often driven by outside investors favoring such moves. In fact, local governments are involved worldwide in land grabbing, relocations and evictions in the legal name of 'development' or 'the public interest'.

${ }^{25}$ Robin Palmer (Oxfam), about his experience during a long and distinguished career with land agencies in Africa, personal communication, Leiden, 26-29 September 2007. 


\section{(4) A bout economics:}

4.1 N ewly legalized plots will be owned by the poor who will use them for collateral. However, evidence from most countries shows how formalization can drive up prices, stimulating land speculation, and push the poor out to the periphery.

4.2 B anks in developing countries will lend to the poor on small plots of land. Several researchers found, however, that banks in transitional and developing countries do not lend on land. ${ }^{26}$ Banks find it inefficient to conduct due diligence and risk assessment on small, individual pieces of land; and they are reluctant to foreclose ${ }^{27}$ as it costs time and money, and they cannot rely on the efficacy of the legal system anyway. For those reasons micro-credit programs are more likely to contribute to the poor's accumulation and productive use of capital.

4.3 E conomies in today's developing countries will develop along the same lines as the W estern economies in the $18^{\text {th }}$ and $19^{\text {th }}$ centuries. However, the situation is too different today in manifold respects, including (but by no means limited to) the fact that colonial exploitation and slavery contributed to the wealth of western nations (Von BendaBeckmann, M ysteries of capital or mystification of legal property).

\section{(5) A bout sodial norms:}

5.1 L ocal informal austomary rules can be codified into national law without causing major social problems. This assumption, which is the core of the first part of De Soto's strategy (see above) overlooks the common phenomenon of multiple use rights on one plot of land, especially secondary rights of vulnerable groups such as pastoralists, slash-and-burn cultivators, and women in general.

5.2 It is possible to make legal rules, which are fix ed, precise, neutral and final, based on the unwritten local conventions of the people which are flexible, relational and processual. This problem has been widely discussed in legal anthropology. So far, no one has found a generally satisfactory solution. In the words of Roquas $^{28}$ who aptly summarizes the difficulty of state interventions aiming at land ownership registration in rural Honduras:

'(..) it is not so easy to establish who a landholder is. The person who possesses the land may not be the one who owns the land; the person who works in the field may not be the holder of the land; the person who has "papers" may not be the

${ }^{26}$ Forbes Davidson (IHS) about major banks in the Balkans, personal communication, Leiden, 26-29 September 2007.

${ }^{27}$ John Bruce, about credit banks in Africa, personal communication, Leiden, 26-29 September 2007.

${ }^{28}$ E. Roquas, Stacked law. L and, Property and $\mathrm{C}$ onflict in $\mathrm{H}$ onduras. Ph.D. dissertation Wageningen Agricultural University, 2002, p. 239. 
same person as the one who has a land title or a registered title deed; and the person who is the holder might not possess any deed of the land.'

\section{Development, Governance, Rule of Law}

For decades policies of developing countries have been aimed at the twin goals of development, i.e., nation-building and socio-economic progress $\left(\right.$ Heady $\left.{ }^{29}\right)$. What is called 'socio-economic progress' can, of course, be broken down in more concrete objectives. A broad consensus has developed about what the most common and urgent social-economic development problems actually are. Undoubtedly they include (1) insecurity and armed conflict, (2) poverty, (3) social injustice and inequality, (4) illiteracy and lack of information, (5) disease, (6) destruction of nature, (7) cultural estrangement and (8) social repression. Engagement with precisely these eight issues has shaped the policy goals of most developing states. These 'goals of development' typically include: security, prosperity, social justice, capacity, health, sustainability, authenticity and social freedom (see Table 1)..$^{30}$ In the international history of development policies, one can notice the emergence of each of these goals, often in relation to specific trends, events and experiences, and their inclusion in formal policies. Most of these development goals are also somehow connected with land policies and land reform.

While there is considerable agreement about these goals, some of which have been further specified in the Millennium Development Goals, there has also been much debate and disagreement about the causes and interrelationships of development problems, and about the relative priority and sequencing of the development goals. The main focus of the development debate in the 1970s and 1980s was on what should come first: economic growth or social justice/poverty reduction through redistribution. Obviously, capitalist worldviews stood here in opposition to socialist ideas. The Soviet-Union, China, Eastern Europe and most developing countries would typically stress social justice, and social and economic human rights. For decades this has conflicted with the United States and Western Europe's focus on market-led growth coupled with civil and political rights. In making these distinctions, however, it is important to keep in mind that there was a good deal of ideological propaganda on both sides of the debate. This conflict has also constantly cropped up in the land sector which is so important for people's livelihoods in developing countries. While the 1960s and 1970s saw increasing

${ }^{29}$ F. Heady, Public A dministration: a C omparative Perspective, 1996, pp. 290-300.

30 The formulation of these goals is informed on the one hand by how national and international development policies defined them, on the other hand by how ordinary, poor people in developing countries have defined their needs and goals, according to numerous field studies and press reports. It builds on literature about development policy such as Esman (1991). 
Table1. Development: problems, goals, processes

\begin{tabular}{lll}
\hline Problems & Goals & Processes of development \\
\hline 1 Insecurity & Security & Protection of public order \\
2 Poverty & Prosperity & Economic growth \\
3 Social injustice and & Social justice and & $\begin{array}{c}\text { Redistribution of income \& } \\
\text { rights }\end{array}$ \\
4 Lack of knowledge & solidarity & Education \\
5 Diseases & Health & Health care \\
6 Destruction of nature & Sustainability & Environmental protection \\
7 Cultural estrangement & Authenticity & Cultural identification \\
8 Social repression & Personal freedom & Social liberalization \\
9 Bad governance & Good governance & Improvement of governance \\
\hline
\end{tabular}

intervention by governments in the land sector in accordance with socialist notions such as central planning, public or collective ownership, land reform, redistribution, strengthening the position of tenants, agricultural cooperatives, we have noticed since the 1980s an increase of market-oriented land policies, a greater focus on private individual ownership, titling and registration and the creation of land markets, a rolling back of programs that had redistributed land and strengthened the position of tenants, and a reduction of public and cooperative structures.

De Soto's position in this debate is equivocal. While De Soto himself presents his plans embedded in a discourse of poverty reduction, much relevant research indicates that his plans help middle and higher income groups rather than, or more than, the poor. While the discourse hints at social justice and redistribution, the underlying policy theory of this economist exhibits, not surprisingly, a strong belief in neo-liberalism and market-led economic growth.

Meanwhile, since the early 1990s, the international development debate has identified an additional key problem of development with a negative influence in many areas including the land sector: bad governance. 'Good governance' as a new goal of development includes, roughly speaking, four major dimensions, i.e., (1) nation- and state-building, (2) democratization, (3) sound administration, and (4) the rule of law (see Table 2). ${ }^{31}$

\footnotetext{
${ }^{31}$ Important introductions to this concept can be found in Hyden, et al., 2005 and Kraay Kaufmann and Zoido-Lobaton, 1999.
} 
Table2. Good governance: problems, goals, processes

\begin{tabular}{|c|c|c|}
\hline Problems & Goals & Processes \\
\hline 1 Failing state & Effective \& legitimate state & State- \& nation-building \\
\hline 2 Autocracy & Democracy & Democratization, empowerment \\
\hline $\begin{array}{l}3 \text { Ineffective, inefficient } \\
\text { unreliable administration }\end{array}$ & $\begin{array}{l}\text { Sound (effective, efficient, } \\
\text { reliable) administration }\end{array}$ & $\begin{array}{l}\text { Administrative development, } \\
\text { institution-building }\end{array}$ \\
\hline $\begin{array}{l}4 \text { Injustice \& lack of } \\
\text { legal certainty }\end{array}$ & Rule of law & $\begin{array}{l}\text { Strengthening legal system, } \\
\text { towards rule of law standards }\end{array}$ \\
\hline
\end{tabular}

In its 1994 report 'Governance: the World Bank's experience', governance was defined as 'a predictable and transparent framework of rules and institutions for the conduct of private and public business.' The emphasis is on the predictability and transparency of rules for conducting 'business', and thus on legal certainty rather than social justice. Other definitions of governance, such as the $2000 \mathrm{Re}-$ port of Australian AID on the Indonesian Governance Sector, include ' (...) democratic and community participative practices', or the rule of law, as in 'Governance Matters' (Kaufmann, et al. ${ }^{32}$ ).

Similarly, rule of law means different things to do different people.

It is common and useful to distinguish two dimensions in the 'rule of law'. The classical distinction is between procedural elements and substantive elements of the rule of law. The procedural elements are to make the 'law machine' technically work, so to speak, i.e., they are about production of clear and consistent legal rules and efficient implementation, compliance and enforcement. The substantive elements are about 'justice', they refer to the moral foundations of the law, to fundamental conceptions of justice, and in particular to human rights.

While much of the recent literature on rule of law promotion discusses 'legal development' or 'law reform' as a sector by itself, focusing on legal institutions and processes, it should be acknowledged that law relates to virtually any sector of development and governance, whether security, health, economic growth, redistribution, education, cultural authenticity, personal freedoms, nation-building, democratization, etc. Law is used by states as an instrument of development policies, by market parties as an instrument of economic activity, and by NGOs as a channel for helping the poor in obtaining access to justice. This variety of users, ideologies and objectives is reflected in international rule of law promotion. Behind the neutral phraseology of 'law', rule of law promotion includes elements of (na-

${ }^{32}$ A. Kraay Kaufmann and P. Zoido-Lobaton, A ggregating G overnance Indicators, Policy research working paper No. 2195, 1999. 
tion)-state-building and market-oriented projects alongside human-rights oriented projects. While modernization theory suggests that these elements can and should go nicely together, several contemporary analysts have recognized serious contradictions in the rule of law project (Kennedy ${ }^{33}$; Trubek $^{34}$ ).

In so far as De Soto's program is mainly a plea for having a predictable and transparent land law, and for having as much land as possible registered under such law, the emphasis seems to be on the procedural side of land law. There is much less emphasis in his work on the substantive dimension, i.e., on the justice side, the side of people's 'rights' to land. De Soto has surprisingly little to say about the concrete situations of conflicting and overlapping claims to land, often by unequal parties, which are omnipresent in most developing countries. Characteristically, these problems are rooted in a history of subsequent regimes, laws and claims. Searching for solutions in such contexts is inevitably highly political.

\section{Lessons From the De Soto-Story: Success in Spite of Failures}

The M ystery of Capital stands out as a landmark in the debates over development policy, poverty alleviation, land tenure management, economic growth and rule of law promotion. What lessons can we learn from his work and the subsequent praise and critique for an effective, realistic rule of law promotion?

It seems to me that De Soto, in spite of his mistaken assumptions, deserves credit for a number of achievements. ${ }^{35}$ Firstly, for having demonstrated beyond doubt that problematic access to bureaucracies and their implementation of law often frustrates development, and that something should be done about it. Secondly, for having stressed the importance of rising land values and having tried to let the poor possessors benefit from those rising land values. Thirdly, for having put issues of land tenure security, especially in urban areas, higher on donor agendas. And, fourthly, for having put the access-to-justice and legal-empowerment dimensions of strengthening legal systems higher on donor agendas.

De Soto's work also illustrates how much donors and governments are attracted by good stories promising 'shortcuts to progress', which then creates a momentum for change, even if the strategy is flawed, and so many know it is. In addition,

${ }^{33}$ David W. Kennedy, 'Laws and developments', in John Hatchard and Amanda PerryKessaris (eds.), L aw and development: facing complexity in the 21st century: essays in honour of Peter Slinn, 2003, pp. 17-26. Available online: http://www.law.harvard.edu/faculty/dkennedy/publications/ development.pdf.

${ }^{34}$ D. Trubek, 'The 'Rule of Law' in Development Assistance: Past, Present and Future', in D. Trubek, A. Santos (eds.), The N ew L aw and E conomic D evelopment: A C ritical A ppraisal, 2006.

35 The assessment in these concluding remarks owes much to a paper by John Bruce, presented at the final conference of the Leiden project in September 2007. His paper will be published in a forthcoming book with Leiden University Press. 
it illustrates the fundamental inconsistency of many law reform initiatives that begin with the interests of the poor (rights-based) and often end with increased opportunities for the rich (title-based), unless deliberate pro-poor project interventions are actually made.

Finally, the role De Soto's work has played illustrates the constant need for experts in land tenure and socio-legal studies, whose story-lines have often been too complex and have scared donors away, to organize, package and sell their expertise and advice better in order to be heard. 